
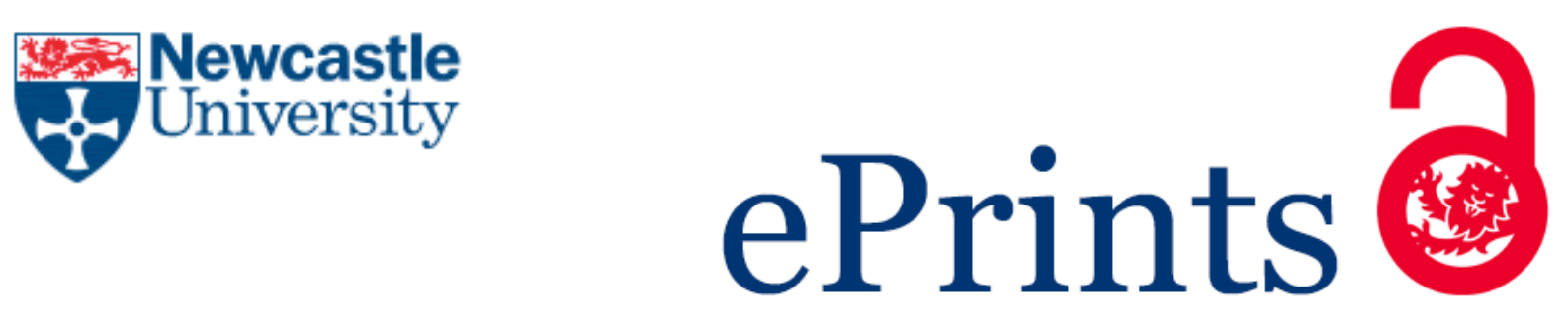

Johnston C, Pratt G.

Tlingipino Bingo, settler colonialism and other futures.

Environment and Planning D: Society and Space 2017, 35(6), 971-993

\title{
Copyright:
}

This is the authors accepted manuscript of an article that has been published in its final definitive form by Sage Publications, 2017

DOI link to article:

https://doi.org/10.1177/0263775817730699

Date deposited:

$15 / 11 / 2017$

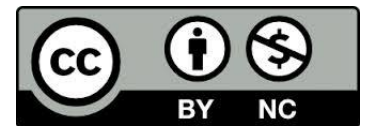

This work is licensed under a Creative Commons Attribution-NonCommercial 3.0 Unported License 


\section{Tlingipino Bingo, Settler Colonialism and Other Futures}

\section{Authors' Contact Information}

Dr Caleb Johnston

School of Geography, Politics and Sociology, Newcastle University

Newcastle Upon Tyne, United Kingdom, NE1 7RU

Tel: 4401912083950 Email: caleb.johnston@ncl.ac.uk

Professor Geraldine Pratt

Department of Geography, University of British Columbia

1984 West Mall, Vancouver, British Columbia, Canada, V6T $1 Z 2$

Tel: 16048222663 Email: gpratt@geog.ubc.ca 


\section{Tlingipino Bingo, Settler Colonialism and Other Futures}

What new narratives might emerge as labour migrants and refugees are more and more articulated as threats and targets within right-wing populist and nationalistic politics in North America and Europe and elsewhere, and how can we put our research to work to create the kinds of worlds we want to live within and the kinds of public discussions to which we aspire? These are discussions grounded in lived realities, empirical evidence and considered judgement rather than wilful ignorance, polemic, fear and hate. What we describe here is the latest iteration of an on-going experiment to work with performance as a means of translating and transforming scholarly work so as to generate a more deeply felt, more vulnerable, more informed and more nuanced public debate on migrant labour. Performance has become a method of working, a means of opening up to new sites of learning and unlearning, of producing new research encounters, and a way of doing research and theory. ${ }^{1}$

Our turn to theatre produced in the first instance Nanay, a testimonial play constructed and performed as a collective of verbatim monologues developed from research transcripts, many conducted in collaboration with the Philippine Women Centre of BC, with Filipina migrant domestic workers, their children, nanny agents, government officials and Canadian employers. The original play focused exclusively on Canada's Live-In Caregiver Program, a temporary labour migration program that brings mostly Filipino women to Canada to work in Canadian homes, with the possibility of applying for permanent resident status after completing 24 months as a live-in domestic worker. Nanay has had a long history, and has taken on a life of its own. It has travelled widely from Vancouver (2009) to Berlin (2009) to Manila (2013; 2014), and, finally, in 2015, to Whitehorse in the Canadian North (see Johnston and Pratt, 2014; Pratt and Johnston in 
collaboration with PWC, 2014; Pratt, Johnston and Banta, 2017). We have recalibrated the play to local circumstances, necessitating new research at each new site. The unexpected travels of our play thus have created an opportunity to re-theorise temporary labour migration in unanticipated ways.

When Nanay travelled to Whitehorse, it opened a space for a close consideration of two processes within global capitalism that are often kept apart: racialised labour migration and indigenous dispossession within settler colonialism. This opportunity arose unexpectedly in January 2015 when Nanay was presented as a staged reading as part of the Whitehorse Pivot Theatre Festival. Working with local actors and community members, the recalibrated script included monologues of labour migrants in two temporary migrant programs telling of the great hope of university-educated women from the Philippines for 'finding their luck' in Canada: of gaining permanent Canadian citizenship and creating 'a better life' for their children. The monologues also speak of their challenging circumstances in Canada, including precarious working conditions and long, difficult periods of separation from their families as they strive to secure their permanent resident status so as to sponsor their children to join them in Canada.

The reaction to this script reading in Whitehorse was mixed and that of Filipino audience members differed from reaction in other places. Filipino presence was sparse that day and response tended to emphasize the successes within the community: "I look around," said one Filipino audience member: "They're [Filipinos] actually doing good. They're driving their own car. They're renting and eventually buying their own house. They work two jobs. They work three jobs. They're here. They're willing to work and contribute to the society and community. They're very adaptable. They adapt. And I think that's one of the greatest assets [of Filipinos], 
because they can adapt." Government officials present were even more expansive in the talkback after the reading. One stood to offer this commentary: "I can't speak for the federal government, but I really liked the play. And I found it really interesting in terms of the grey areas because integration is, you know, a big adventure in life. And with adventure comes some pretty major challenges and I would suggest that just about everybody in this room, with the exception of I know of at least one person, has some kind of tie to immigration, in terms of whether their parents, their grandparents, their great great grandparents. And those stories, when you reach into your family history, are built with, you know, adventure. And often very difficult challenges. And I know with my grandparents - every one of them was an immigrant and every one had a really challenging story." This speaker was followed by the individual who the government official had identified as the only non-immigrant in the room. "My name is Sharon," she said. "I'm a Yukon First Nation, and I want to share my perspective, not on behalf of the eight thousand First Nations who live here, but from what I've seen with the community moving here. [...] I realize that as First Nations of the land, that we haven't continued our practice of welcoming people into our territory. Because of all the hardship since the Gold Rush and the [Alaska] Highway coming in, I think we're not as welcoming as we could be. But I would like to find a way to rectify that, to do our traditional welcoming. Thank you for your stories. One of the things that I heard was that family disruption. ${ }^{2}$ I was like, wow that sounds like what happened with residential schools. And I'm sure there has to be a way to dialogue that, to share with each other, to have the compassion for each other, and to make each other human. So my First Nations community, what I'm seeing... what I'm disturbed about is racism against immigrants, in particular Filipinos. And I try to fight against that but it's something that's very... 
something that I want to stop in my community. And I think if people could maybe sit in a circle and tell stories, as is our way, that would be healing."

What emerged from these audience reactions has been a new collaboration, in the first instance, between Sharon Shorty, the Tlingit elder and well-known storyteller and performer who stood up that day, and Hazel Venzon, the Filipina actor and producer who organised the staged reading in Whitehorse, and who has performed in a number of the productions of Nanay. Through a short artist residency in Juneau Alaska in December 2015, Sharon and Hazel conceived a new piece called Tlingipino Bingo, which was collectively built and performed at Whitehorse Nuit Blanche in June 2016. It is this spin-off from our original play that we examine here, to explore ways of responding critically and analytically to Sharon's invitation to share stories and build relations on terms other than those on offer that day, that is: to build relations that move away from a model of minority immigrant success within narratives of state multiculturalism, towards new ontologies of belonging and social relatedness, including familial relations imagined and lived beyond the private family. In seeing the basis for conversation across First Nations' experiences of state-enforced family separation through residential schools and Filipina/o labour migrants' experiences of family separation, Sharon Shorty joins and brought us to ongoing scholarly debates about the relationships between migration and indigenous studies, race and indigeniety, racial global capitalism and settler colonialism, and the possibilities of relationship between indigenous peoples and those forced into the Americas by the violence of European and Anglo-American colonialisms and imperialism around the world (see for example, Byrd, 2011; Chazon, Helps, Stanley, Thakkar, 2011; Day, 2016; Farrales, 
2017; Lawrence and Dua, 2005; Lowe, 2015; Saranillio, 2013; Stanley, Arat-Koc, Bertram and

King, 2014; Tadiar 2015; TallBear 2016; Wong, 2008).
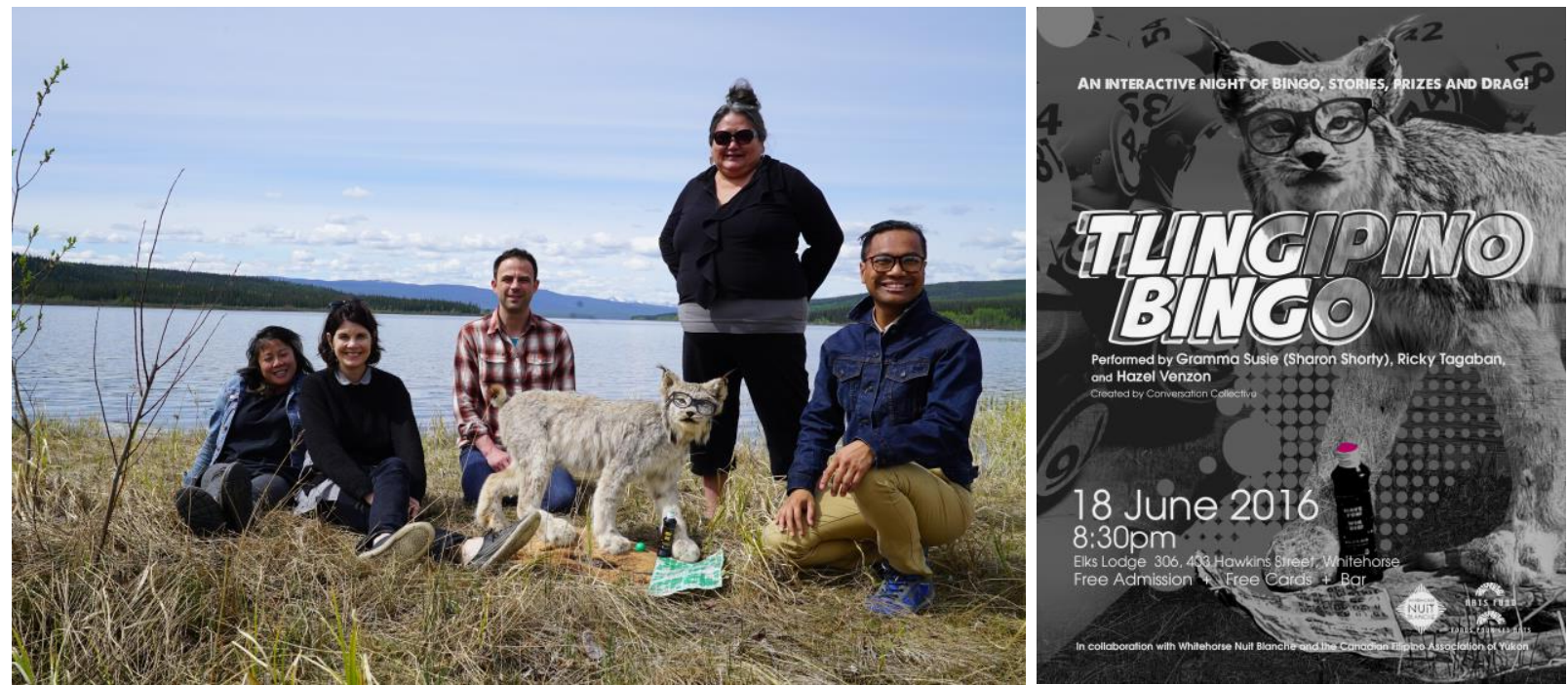

Figure 1. Conversation Collective and Flyer. Photo by Conversation Collective.

Flyer designed by David Oro

As white settlers, we sit awkwardly within this collaboration. While Nanay originated as a staged dialogue between Filipinos and white employers and Canadian state ${ }^{3}$, Tlingipino Bingo staged storytelling across indigenous people and Filipinos in Whitehorse, in the context of a settler colonial society. As 'context' our positionality is both ever present and less specified". The creation of Tlingipino Bingo was a productively discomforting process sitting within an indigenous-arrivant-settler triad. This is no less the case for this critical reflection. We document the public event of Tlingipino Bingo (and draw on additional research materials from Whitehorse ${ }^{5}$ ) to interrogate how deeply settler colonialism burrows into everyday life, including - perhaps - practices of racialised immigrants, the ways that a model minority discourse functions within state multiculturalism, and to imagine other futures beyond settler colonialism, which could possibly include us as allies. Embedded within the specifics and logics 
of settler colonialism and the racial dynamics and concerns of a small city in Northern Canada, Tlingipino Bingo might also help us all to think strategically about possible critical responses to contemporary claims of dispossession by white citizens in Canada and elsewhere, as well as their destructive nostalgia for a lost national time of whiteness.

\section{Setting the Stage: Filipino Labour Migration and Settler Colonialism}

Sharon Shorty's observation about antagonism between local First Nations and Filipinos in Whitehorse was mirrored in conversations with some (not all) Filipino residents. Some spoke from their own experience: "I was walking along Third Avenue, and then these two First Nations were coming towards me and I was putting coins in the meter, and they yelled at me: 'Go back to where you came from'” [Interview A]. More common, stories of negative encounters circulated as hearsay, along with rumours of a Facebook page in which hostile comments could be viewed. Conversely, some Filipino community members voiced their own stereotypes and resentment about First Nations' peoples. "They call them pana. P-a-n-a. Pana. So that nobody knows that we're talking about them. And there's some resentment that they get more, they have more. You know, when they're in school they get this and they get that" [Interview B]. Several Filipino residents responded to the accusation that they have stolen jobs by calling up their capacity as workers and their obligation to family: "I think there's jealously because you see so many Filipinos driving brand new cars, owning a house, so progressing in their lives because, first and foremost, they came here for economic reasons. [Enjoying life is] not what we came here for. It's not just to get by but to provide for ourselves and then help other family members. And that's the strength of the Filipinos" [Interview A]. From another Filipino 
community member we heard: "Some of the First Nations would say: 'You're taking away jobs from us'. But what I've heard from employers is: 'How could we employ them, if they are not educated for their jobs? Like we will train them for a few weeks, and then after a few months they will just say, 'Goodbye. I can't work for you anymore because there are personal reasons'” [Interview C]. This community member noted that Filipinos are willing to work diligently at lowlevel service jobs even after they have fulfilled the terms of the immigration program that brought them to Canada: "Especially under the Yukon Nominee Program, although they are required to stay for two years [with the employer who sponsors them], many of them stay working with them longer than their contracts. Some of them came in 2007 [to work as clerks for Canadian Tire] and they are still there." One Filipino resident reasoned that one implication of this capacity for hard work and reliability as workers is that there is often little time for Filipino immigrants to learn about the history of settler colonialism in Canada: "Not a lot of Filipinos really know the story of First Nations... A lot of Filipinos don't have time to read or to go to college. Because they're here to work. Time is money. Per hour. 'If I could fit 3 jobs into 24 hours, that's great.' Two jobs maybe. So they're here to work. They're here to make money. It's not monthly... In the Philippines you're paid by the month. By the week, or twice a month. Here it's per hour. Per hour for them is a new notion. It's like, 'Oh my god, I can make money. Like a lot of money. Per hour'” [Interview B]. The same community member suggested further that even when histories of colonialism are known by Filipinos, there may be reluctance to assume responsibility for colonial legacies and traumas in the Canadian North because they predate their arrival. 
These observations among Filipinos are embedded in stories about two phases of Filipino immigration to Yukon. The first is narrated around seven successful nannies, whom we heard about again and again during our time in Whitehorse. This story was so common that when we mentioned it to a non-Filipino government official, he said, "Oh, so you've heard the story." The narrative is about seven single Filipina women, friends who attended the same church while working as domestic helpers in Singapore in the 1980s. One found employment in Yukon as a live-in caregiver in 1984, and by the early 1990s the other six had joined her in Yukon, also as live-in domestic workers. These seven women have been successful in many ways, including purchasing houses and in some cases starting businesses. One of the successful nannies told the story of property ownership in this way:

1991, 1992: I called [three other nannies] one day and said, 'Let's put our money together and buy a house.' Because we were just nannies, right?, we were kind of jokingly saying, 'Are you dreaming or hallucinating?' And I said, 'There's no harm in trying. We can just check it out.' I remember we got dressed up, because we really wanted to represent ourselves. We go into the CIBC [Canadian Imperial Bank of Commerce]. It was really easy. We never thought [we would get a mortgage]. At that time we were being paid 6.50 an hour. So we put our salary [together]. And then we were laughing because when we came out -- after 15-20 minutes -- we were preapproved for [a] $\$ 160,000$ [loan]. And we never thought [that was possible]. We thought it would be so hard! But then, anyway, we started being picky because we realized how easily we can come up with the money. So we went to the other bank as well, because at the CIBC there was a lady there that kind of treated us differently. And then 
somebody told us, 'You guys, you're really not asking their favour. You're giving them business, eh?' So it's something that we have to be proud about. But being a nanny, it's so hard to put that in your mind. We were the first Filipino nannies buying a house. So that kind of opened an inspiration to others. Two years later on, two partners went out and bought their own place too, and it started just stirring up inspiration for others to buy a house.[...] Same thing with the car.

They became known as the 'Teslin girls' for the street on which their house was located and their home would become a gathering place within the community.

One of the seven nannies' most influential successes has been to sponsor large numbers of family members since 2007 through the Yukon Nominee Program. This is an immigration program that allows employers, who can establish to the government that they cannot find Canadian citizens or permanent residents to fill their jobs, to nominate non-Canadians to do this work. Workers come under a temporary work permit and have the opportunity to apply for permanent resident status within the Yukon Nominee Program, at which point family dependents also can be sponsored. A government official associated with the program confirmed that until relatively recently the program was run by two people "kind of off the side of their desks." He acknowledged that several of the successful nannies had seized the opportunity of an initially under-regulated immigration program by approaching Whitehorse employers to say "Looks like you need some people working in your business," presenting resumes of family members and doing the necessary paperwork to enable these employers to nominate their relatives through the Yukon Nominee Program. ${ }^{6}$ Successful nannies' creative manoeuvring within a formerly loosely regulated program, which is explicitly geared to 
employer need and labour market requirements, allowed them to sponsor many family members relatively quickly. Between 2007 and 2016, 410 workers from the Philippines and 382 of their dependents came to Yukon through this program, almost all as low-skilled (or what the government calls 'critical impact') workers (food counter attendants, light duty cleaners, cashiers, sales clerks, and store shelf stockers are among the most common occupations included within this designated classification). Repeating a familiar pattern of racialized labour migration, Filipinos are noticeably over represented among critical impact (as compared to skilled) workers: half of all critical impact workers are from the Philippines, and only $12 \%$ of Filipinos come as skilled workers as compared to $68 \%$ of those coming from places other than the Philippines.

The effects of the Yukon Nominee Program are highly visible in the Whitehorse landscape. In the words of a local Filipino resident: "You know the hotels, it's all Filipinos now. The restaurants, the fast food, the Canadian Tire, Home Hardware, Superstore. It's all Filipinos. McDonalds. It's all Filipinos. Tim Hortons..." One government official estimated that Filipinos now comprise between $5-10 \%$ of the Whitehorse population. There is now a competitive Filipino basketball league in Whitehorse. There are Filipino restaurants (e.g., The Talk of the Town restaurant) and remittance sending agencies. The Superstore stocks an array of Filipino foods, everything you need to make halo halo. The Philippine Asian News Today is widely available, and there's a small kiosk in a local mall where one can buy and send balikbayan boxes or directly purchase gifts - flowers or a birthday meal at Jollibee's - for one's family or children in the Philippines. 
Less visible is the creation of what is regularly referred to as clans within the Filipino community. One of the successful nannies estimates that she has helped to bring more than 30 family members, who have then sponsored their dependents. Altogether she estimates that she has helped 75 relatives and people from her village through the Yukon Nominee Program. Speaking of a number of the successful nannies we were told: "They just brought the barangay [village] here." An article in a national magazine, The Walrus, states that one of these women almost "single-handedly transplanted a community from the Philippines to Whitehorse" (Keevil, 2016). Several Filipino community members speculated that the successful nannies' agile use of the Yukon Nominee Program has defined social and economic relations within the Filipino community in Whitehorse, in both positive and potentially troubling ways. Without necessarily leading to this outcome, it has created structural conditions for possible exploitation within Filipino families, as newcomers are obliged to repay their debt of gratitude to the family member who arranged their sponsorship (Davidson, 2012). Some Filipino community members also noted that it potentially creates a pool of quiescent workers in low-level service jobs under conditions where it is difficult to challenge an employer, because this would bring shame to the family member who recommended them for the job.

How Filipino migration to Yukon can be thought in relation to settler colonialism is an open, contested question. Within debates about the relations between settler colonialism and racialised labour migration one point is clear: these experiences cannot be collapsed into each other. Racialised immigrants' experiences of labour exploitation, and indigenous peoples' dispossession from land and resources are distinct processes within global capitalism. The logics of racial exclusion are different than the logic of elimination, and the possibilities for solidarity 
lie in what Tuck and Wang (2012) have termed an "ethic of incommensurability." Jodi Byrd (2011) urges that we read the 'cacophonies' of colonialism as they are rather than attempting to hierarchize, equate or place them in causal order. The processes are nonetheless conjoined in specific histories of violence in specific places: genocide and dispossession cleared the land for the use of indentured labour; and indentured labour was in some places introduced as a kind of solution to political pressure to abolish slavery (Lowe, 2015). Jodi Byrd argues that ideas of Indian and Indianness have functioned as the 'transit' of U.S. empire, the "ontological ground through which US settler colonialism enacts itself as settler imperialism" (2011: xix), a claim that demands close attention in the Philippines, where the U.S. colonial experience has been so formative. For example, modes of warfare and actual high-ranking U.S. army officers from the wars fought with Plains Nations in North America were directly transported to what Hedman and Sidel (2000) term "the United States' first armed adventure in Asia" (38): the PhilippineAmerican War 1899-1902 (see also Miller, 1982). Neferti Tadiar (2015: 143) documents how the incorporation of the Philippines into US domestic space as a colonial acquisition "bore the legal memory" of earlier landmark legal cases framing citizenship for African and Native Americans in the United States. In not extending the Fourteenth Amendment of the US Constitution to the Philippines as an unincorporated territory in 1901, "we could say Filipino is racialized as not black, and like Indian" at one defining moment in its national formation. As in the case of indigenous peoples and slaves, the withholding of U.S. citizenship to Filipino colonials, she argues, "set precedents for deeming what is outside the national rule of law as also outside the bounds of civil and human status, which continues to be reflected in the attitudes today towards 'illegals' (as forms of non-personhood)" (143). 
Alongside these interwoven histories that create the ground for solidarities, immigration can and often does reinforce the colonial and multicultural state. As Patrick Wolfe (2006) has argued, there is nothing preventing even colonized natives from one region becoming settlers in another if their actions support the dispossession of indigenous peoples in the new locale. As Dean Saranillio notes (2013: 286), "Power does not simply target historically oppressed communities but also operates through their practices, ambitions, narratives and silences." Is it significant that the seven successful nannies are regularly referred to as pioneers within the Whitehorse community? Do Filipino homeownership and incorporation within circuits of finance capitalism signify processes beyond immigrant success? Have the seven successful nannies delivered almost a thousand well-educated, quiescent workers to Whitehorse service industry employers, even as they exercised their ingenuity to reunite their extended families and barangay relations in Yukon? Is the following a harmless slip? "We were joking that there's only between 29,000 to 32,000 in a land area three times bigger than the Philippines. We are 98 million at the present in the Philippines. [...] I said, 'There's still space that we can fill in." The seven successful nannies' and other Filipino immigrant stories in Whitehorse create uncomfortable, immensely productive moments in which the figure of Filipino-as-victim of empire crashes up against Filipino-as-settler in profoundly destabilising ways. ${ }^{7}$

As non-Filipino, non-indigenous scholars we are drawn to comment on these narratives because they do considerable ideological work beyond the Filipino community. We heard them from non-Filipino government officials and they are widely circulated in the local and national media (e.g., Alarcon, 2013; Clarkson, 2015; Da Souza, 2012; Hopper, 2009; Oke, 2011; Ronson 2013; Thompson 2010; Walcher, 2014; Wingrove, 2014). Hard working Filipinos, working 2-3 
jobs to amass all that is possible in 24 hours on an hourly wage, persevering in their jobs at Canadian Tire long after their temporary work permit requires it - this fits within a long history of configuring Asian workers within a 'natural' appetite for hard work. The hard work, sacrifice and success of Filipinos in Whitehorse are not at issue. However, this discourse does significant ideological work within the wider Canadian society. It marks Filipino racial difference and renders Filipinos as hyper economic embodiments of laissez-faire capitalism. lyko Day (2015) traces in the Canadian context the extent to which this portrayal of Asian labour has both marked Asian labour as 'model minorities' and historically been a source of criticism from white workers, who feel that Asian workers' appetite for self-exploitation has undermined white workers' wages and working conditions and capacity for human and humane conditions of social reproduction. In other words, historically this appetite for hard work has been used to render Asian workers as somewhat less than fully human. Stories of hardworking immigrants' success simultaneously sustain a powerful liberal narrative of the racial neutrality of the state and capitalist economy (i.e., we all can be successful regardless of race), as well as a narrative of equality and progress towards a post-racial society (Honig 1998; Palumbo-Liu 1999). ${ }^{8}$

Played out directly in relation to indigenous Canadians, the narrative of hardworking Filipinos does further ideological work. By rendering indigenous peoples as indigent and incapable of disciplined labour in invidious comparison, it breathes new life into an argument that laid the philosophical foundations for British claims to property in North America and justified dispossession of indigenous peoples from their lands: this is the Lockean argument that appropriation through labour underpins rights to ownership. The complexity of Filipinos' positioning within settler colonialism brings all of us to the reality that settler colonialism is a 
violent ongoing process, often unwittingly enacted by sympathetic well-meaning people with complicated lineages and relationships to it. ${ }^{9}$

Tlingipino Bingo entered into this fraught politics and worked with these complexities and complicities in ways that we turn to discuss. Through our presentation of the performance, we lay out some strategies for a prefigurative politics beyond liberal forms of inclusion and exclusion, including perhaps, alternative narratives of Filipinos beyond self-exploiting model minorities.

\section{Joking Across Colonial Traumas}

Tlingipino Bingo was an interactive improvised bingo game performed at the Elks Lodge 306 in Whitehorse as part of an all-night arts festival. The bingo game provided the structure within which three performers improvised. It grew out of Sharon and Hazel's discovery during the artist residency of a shared enjoyment of bingo within First Nations and Filipino communities, typically played, however, in different places in Whitehorse: at the Elks Lodge (and as TV bingo during the winter months) for the former and at private parties for the latter. Their objective was to work with their communities' mutual enjoyment of this game of chance to get them into the same space to play together and share stories. We arranged for one 'plant' in the audience, but much of the performance was unplanned, itself left to chance and the improvisational instincts of the performers. We put together a series of prizes - bags of rice, a basket of ingredients to make moose adobo, a balikbayan box, chilkat woven earrings, a bucket of Kentucky Fried Chicken, Aunty Wilma's canned salmon, among other prizes that we hoped would prompt the sharing of stories. 
The Elks Lodge runs a bingo every day of the week, twice on Saturday and Sunday. Each game takes about two hours but many bingo players come hours in advance to claim their lucky chair. Roughly 140 to 160 people come out for each game, the same 75 to every game, and some players travel 100 miles to play. In terms of the bingo players, it is an indigenous space: an Elk who has been running the bingo for 40 years estimated that $60-70$ percent of the players are members of First Nations. We scheduled Tlingipino Bingo right after the Saturday night game to keep these players in the audience and worked with the Canadian Filipino Association of Yukon (CFAY) to bring the Filipino community out.

The Master of Ceremonies was Sharon Shorty, performing in character as Gramma Susie. Gramma Susie "came to life" in 1996, and was intended as a one-time performance with her friend, Jackie Bear, another Whitehorse indigenous artist. They brought together their shared history of being raised by their grandmothers and improvised their characters, Susie and Sarah -"two old ladies always laughing about something" - as a way of respecting and honouring their elders. Gramma Susie has lived on and Sharon is now a well-known and wellrespected award-winning performer and storyteller, who performed at the Truth and Reconciliation National Event in Winnipeg in 2010 and was part of the Yukon First Nations contingent to 2010 Winter Olympic Games, among other notable performances. There is a display of her iconic outfit at the Museum of History in Ottawa, with each item carefully catalogued in the digital archive. Gramma Susie was, in other words, a familiar character to at least a portion of the audience at Tlingipino Bingo. She is "feisty, opinionated and funny," an elder who delights in cutting "big shots" down to size (http://www.sharonshorty.com/historysc.htm). Of the territorial premiers who she has forced 
to learn the Indian dance over the last twenty years she says, "Some of them are really scared of Gramma Susie because she's very politically astute. Knows what's going on. Knows their weaknesses." She uses her sharp wit to confront settler colonialism with humour, by telling stories about meeting the Queen, Prince Charles and Colonel Sanders, the latter a source of sustained romantic attraction.

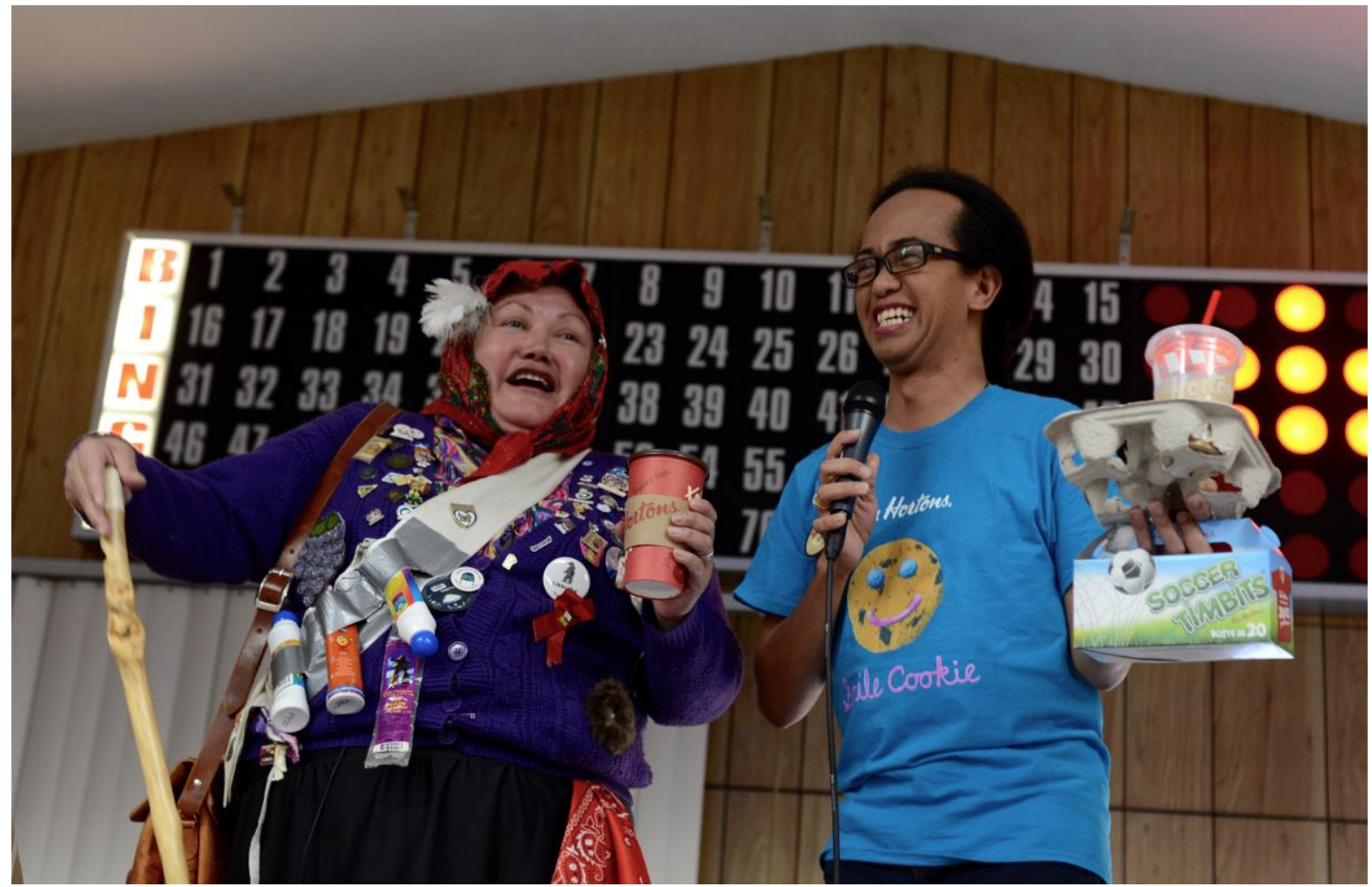

Figure 2. Gramma Susie and Ardie. Photo by Anna Crawford

Gramma Susie began the performance/game by taking note of her surroundings, facing off with a display of Elks at the end of the hall: one massive stuffed animal head amidst framed photographic images of past presidents of the Benevolent and Protective Order of Elks of Whitehorse, all white and all but one male, not surprising given that the first women were admitted only in the 1990s and the all-white clause of the Order of Elks' constitution was revoked only in 1976, with the proviso that it could be reinstated if the law allowed. "For 
goodness sakes" Gramma Susie said, "I like these guys. They look like Grand Poobahs from -what do you call it? The Flintstones!" She welcomed the crowd by calling out first Filipinos, then First Nations, then artists, then Chinese and then Tlingit to identify themselves. As she was equivocating from her role as bingo caller she detected the Filipino performer, Ardie, in the crowd and called out "Oh, look! There's Ardie from Tim Hortons" and brought him on stage. To the audience: “Listen, this is Ardie. He's my favourite server at Tim Hortons." To Ardie: "I didn't know they do delivery now! Wow. Just for Susie. Listen, Ardie, I'm pretty tired out and you're Filipino. You can handle one more job, can't you? Can you call bingo numbers for me? I'll hand out your timbits [bite-sized donuts]. I'll do your job, you'll do mine. Fair trade. Listen, I want to ask. Welcome to the Yukon, our home. This is our special cultural gathering. It's called a bingo hall, and that's where we hang out. Why did you come to Yukon?" And so it went, Ardie called the numbers and Gramma Susie handed out timbits and cruised the crowd for stories.

As chance would have it, the same white audience member won the first two prizes. After the first win, Gramma Susie told him: “Don't win anymore tonight." When he won again, she said "I told you not to win again" and threatened to beat him up. Ardie intervened: "Gramma Susie, I think we have a special guest in the house tonight to share a story." Gramma Susie quipped: "Well, she almost won in the bingo but [the two-time winner] stole it. Take away his cards." "Now, listen," she said, "we just handed out some white rice [for a prize]. I was meeting my new friend... Marivic could you stand up?" She explains that she and Marivic (the woman identified by Ardie and the only 'plant' in the audience) had been talking about what they liked. She likes the white man Col. Sanders and she asked Marivic to tell the audience what 
she liked in the Philippines. Marivic responded with a story she had shared with Sharon in advance:

When I was a little girl, I'm dreaming to be a white. I was bullied during grade school. They said I was so dark, so I was dreaming to be white. When I grew up and got a job, and I had a friend, a dermatologist, she said: 'I can make you white.' There's a pill I took, and after 7 days, I was white. But I didn't like it because I looked Japanese [not myself] and I decided I like me being brown.

"Well, look at that," said Gramma Susie, placing her arm alongside that of Marivic. "We're just about the same colour. Look at that. Beautiful, right? Thank you, Marivic, for sharing your story. Hopefully this time you get a good bingo." Marivic's story about her desire for and efforts to achieve whiteness is an intimate story about the enduring violence of U.S. colonialism in the Philippines. The combination of armpit whitening and glutathinone tablets prescribed by her trusted dermatologist friend, widely used to alter skin pigmentation, are carcinogenic with side effects that include insomnia, nausea, vomiting, damage to the liver, and cancer. 


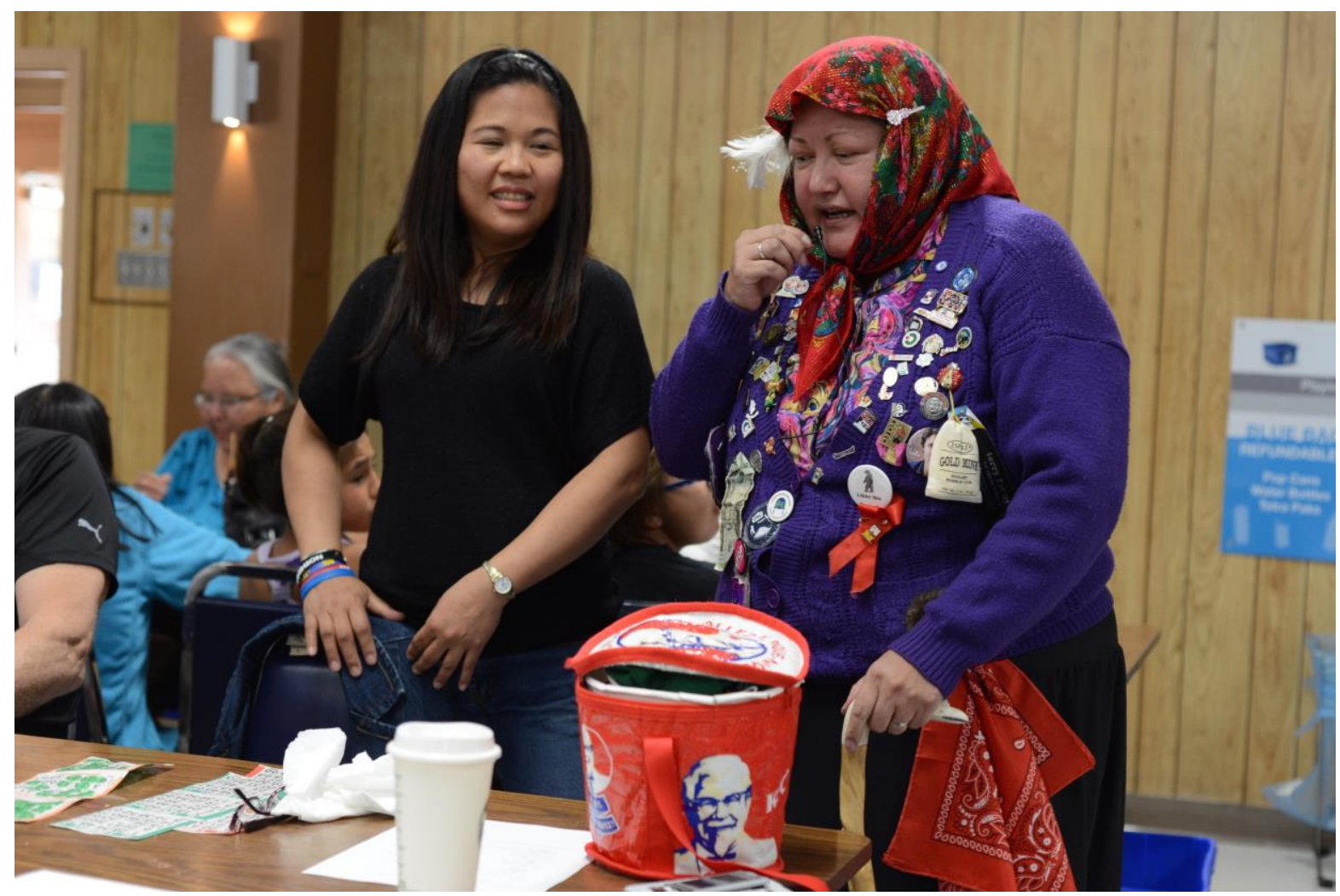

Figure 3. Sharing Stories. Photo by Anna Crawford

Trading stories about desire for whiteness, whether it be embodied by Colonel Sanders or imbibed as potentially life-threatening prescription drugs, joking about Filipinos' labour exploitation in Whitehorse, these are small barbed critiques shared across distinctive colonial histories. When Gramma Susie first met Marivic she shared other stories, including the memory among her people of when they first met white people, the pity they felt for the poor health associated with their pallor, and their efforts to restore white people to health by feeding them meat. Stories open to other stories and our collective hope was that the bingo performance would prompt audience members to reflect on and speak across different but connected traumas, and to think more fully about deeply troubling histories and experiences within two distinctive colonialisms. It is difficult to gauge the extent of reflection, but some white audience members were visibly shocked by some of the stories. 
There is no depth of analysis attending this proliferation of stories - it's just joking around, with gentle teasing and prodding by Gramma Susie. There is a rich tradition of this kind of joking around in First Nations' literature and drama in North America, and considerable reflection on the political possibilities of reframing colonial encounters and racial stereotypes through humour. Speaking about the character of Gramma Susie in the film Redskins, Tricksters and Puppy Stew, Sharon describes laughter as the "greatest joy": "I often think it's a miracle to make somebody laugh. Because you have no idea what will spur that laughter on. And I've thought a lot about what humour is, and what we as native people think humour is. And a lot of times it depends on the chaos. If you look at our history, we've been through a lot of chaos as people. And sometimes chaos makes us laugh". ${ }^{10}$ Humour nurtures resilience and creativity across colonialisms and laughing together (in the face of and in some cases at the expense of white settlers in the audience) works away at the mutual racisms generated across immigrant and indigenous populations, and positions the white settler in a productively awkward relationship to the jokes.

The possibilities of sharing at Tlingipino Bingo went beyond storytelling because of the embodied interactive nature of the performance, of literally playing together. The director tells one small story that gives a sense of the possibility, albeit within the frame of heteronormativity:

[The Bingo performance had] a different way of connecting people. [...] Like, there was this aboriginal woman who came in late, and there's no more bingo cards. And it's her space. [...] I said, "Just wait." I went to a Filipino to ask him if he could give his card to this woman and he said, "Yeah, sure." And I called the woman and I introduced them, 
and he immediately gave the card. He said "I can share one with my wife." Then it becomes a family thing. Giving is important. And allowing yourself to surrender your power, your chance to win. Like you give it to the original people, because of who has been occupying their land. Anyway, it's fun. It's fun to give. It's fun to share. And then, the woman won. The woman won! [The Filipino man who] gave his card. He found me. "Dennis, our card, it was a winning card!" And we're laughing. You could be happy even if you lost your chance. To be a witness of losing but still ending up happy and joyful because anyway he had moments with his wife: sharing, dabbing, looking for numbers. That community-ness is present.

\section{Tlingipino Drag and Rubbing History Against the Grain}

There was a short break after what were called the Filipino and Tlingit rounds of bingo. When everyone was seated once again, MIA's song 'Bingo' blared from the speakers and Miss Lituya entered from the back of the hall, lipsynching and dancing her way to the front on four-inch high heels. The atmosphere was electrified, many phones held high in the air to record the performance, and there was an excited buzz of whispered questioning about Miss Lituya's gender. When Miss Lituya had made her way to the front of the hall, Gramma Susie observed: "You're a tall lady. Who are you anyway?" Miss Lituya explained: “My name is Lituya Hart. I'm a woman of the Coho clan, the clan house that faces outwards. My father's clan is the Wooshkeetaanyádi [Shark clan]. [Sharon:] You're my people: Tlingit. But, you're Tlingipino too." Ardie intervened: “I hear you are half Filipino. Do you speak Tagalog?” Miss Lituya's response that, "No. My great grandfather immigrated to Southeast Alaska from llocos" elicited loud 
cheering from the Filipinos in the room. And so Gramma Susie did a second round of welcoming: "So, here's Gramma Susie welcoming properly, first time ever in the history here at Elk's Lodge, our first ever Tlingipino drag queen." Turning to Ardie, Miss Lituya extended the offer of kin relationship: “Hey cousin, when you're done helping Gramma, could you come and help me call [the bingo], because l'll be delivering the prizes."

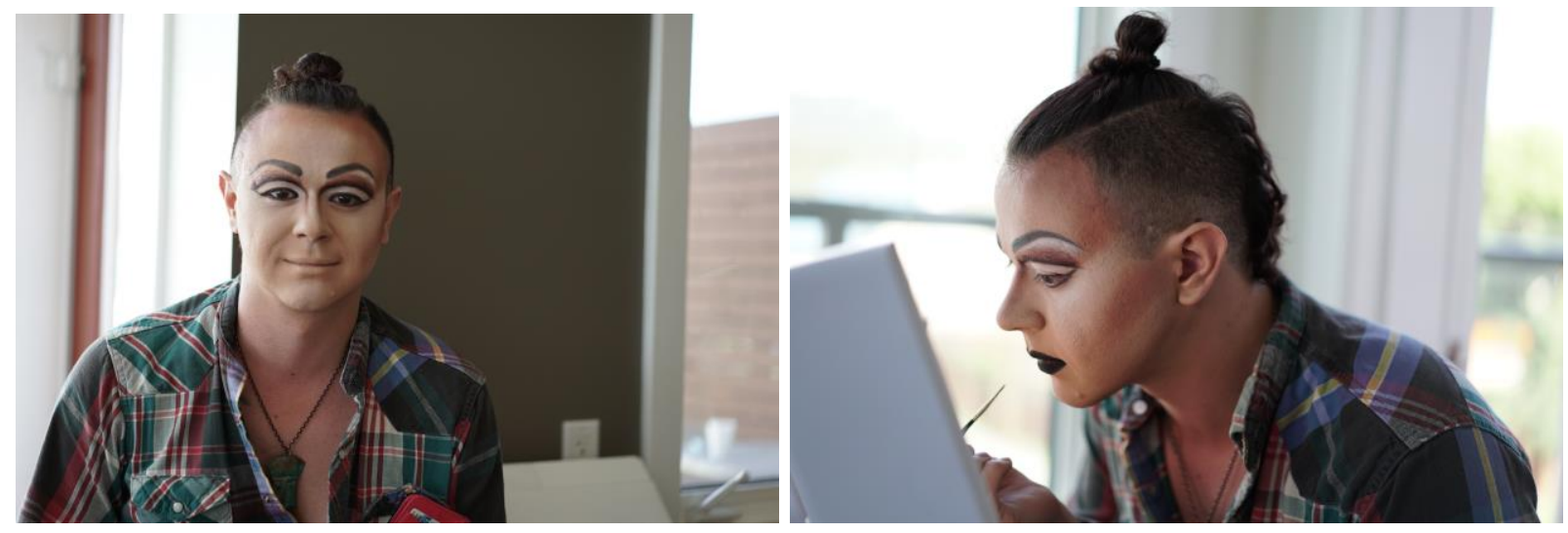

Figure 4. Miss Lituya brought into being. Photos by Vanessa Banta

Miss Lituya is the creation of Ricky Tagaban, a Tlingit artist and storyteller. He has given Miss Lituya a place within his own Tlingit family origins in Lituya Bay. As the fates would have it, Lituya Bay was the site of the largest recorded tsunami in 1958. "To see so much of your family go back to the land after a natural disaster like that," says Ricky, "it reinforces our claim to that place. It's a very Coho place." Ricky is also the great grandson of a Filipino who migrated to Alaska to work as a commercial fisherman.

Miss Lituya is a transformative figure, we suggest in three ways. First, she destabilises conventions of gender, sexuality and race, including white conventions of queer (Morgensen, 2011). Hunt and Holmes (2015: 159) argue that, since gender binarism was inherent to the project of colonial erasure of indigenous peoples, decolonization is "already active" in the lived experience of indigenous queer gender and sexuality. Beyond this, securely situated within her 
Tlingit clan, Miss Lituya does not present in the first instance as queer (or simply so) and her drag character is not easily mapped onto white traditions of drag.

Writing about the Filipino tradition of bakla, Martin Manalansan (2003) argues that it is a mistake to interpret this form of cross-dressing within white drag, which tends towards the more parodic, scandalous and comedic. For Filipinos, he argues, manipulation of surface appearance through cross dressing is not a parody, nor is it done to suggest a consistent gendered self or to unveil something that has been hidden. Rather, the "literal application of layers upon layers of signs of beauty enacts an ontological transformation" (42); it is "playing with the world" (140). Manalanson is drawing on Fenella Cannell's ethnography of lowland Christian Philippines, in which she locates bakla beauty contestants within ontologies of spirit mediumship and relationships to power. In contemporary Philippines, such mediumship has now typically morphed away from spirit mediumship, she argues, towards mediating colonial relations through the power of beauty and the embodiment of American notions of glamour. Bakla beauty contestants "become the temporary bodily 'lodging places for potency'... [recapturing] power, not literally through possession, but through a wrapping of the body in symbols of protective status, and a transformation of the persona by proximity to the power it imitates" (Cannell, 1999: 223). Miss Lituya brought an aspect of this into her performance when, with the guidance of the director, she created as the outer layer of her costume a jean jacket with an agimat (protective amulet) sewn to the back. She explained to the audience: "This is a contemporary agimat. [Interrupted from enthusiastic comments and explanations from Filipinos in audience.] Yeah. So its... [More explanation for audience.] Right. So the intention when you wear this is...you do not get harmed by others. So it's for protection. 
And it's believed to be bullet proof. So it is kind of a sacred garment. And this is Lituya's version of it with the Tlingit leopards on the back of it." [Laughter and clapping from audience.]

Drag characters have been deployed by First Nations contemporary artists, also in transformative ways. In Canada, Kent Monkman, a prominent artist of Cree and Irish ancestry, displaces popular visual imaginary of indigenous men as doomed lamentable 'Noble Savages' and reanimates Canadian history through the antics of his drag character, who he both performs and paints. He has painted Miss Chief Share Eagle Testickle, for example, into Robert Harris's famous group portrait of the Fathers of Confederation: "She's trying to get a seat at the table," he explains, "or she could be a hired entertainer" (Monkman quoted in Everett-Green, 2017).

Miss Lituya disrupts national history in another way: she is living proof that there is nothing new about Filipino migration to the region ${ }^{11}$, potentially opening history and the narrative of the Canadian nation in provocative and promising ways insofar as the primacy of white over Filipino settlement is somewhat disrupted. Miss Lituya not only embodies this history herself, but other histories of Filipino-Tlingit exchange gathered around Miss Lituya and the project. We were surprised when we visited Teslin, the location of Tlingit self-government, at the beginning of our process, and were told a story by an elder about her trip to the Philippines in 1976. She visited for a month, mostly in Baguio, where she met with the faith healer, Agapao. She had especially fond memories of a trip to Manila, dancing with a Filipino man named Romeo at the All American Bar. Our surprise itself tells the story of "the colonization of memory and of events that come to be known as "History'” (Mikdashi, 2013: 
32). Similar stories kept returning in different ways. At Tlingipino Bingo this story told by an elder won the grand prize:

Well, this is the most fun I've ever had in my life in the bingo hall. In 1977 , I had the opportunity to go to the Philippines, and I went to Baguio City. And when I went there, everybody wanted to come home with me. [Addressing Filipinos in the audience:] It took a long time for you to get here but l'd really like to welcome you and tell you a story about what happened when I was there. My auntie Angela -- some of you may know her -- she went shopping. There's two things that happened. First of all, we were in a bus. You know in Baguio what it's like, and Auntie was about 77 at that time. Everybody was in the bus, and the bus stops and the bus driver said, 'Anybody want to go and take a look at the city?' My auntie says, 'I do'. So, she gets off and everybody was shocked. 'Where is she going?' Anyway, she got off and went shopping, and she goes into this store and says 'I want to buy a dress.' They say, 'What size?' 'You know my niece Shirley? She was here 1977.' This was about 1979, and they say, 'Yes'. Which they didn't. 'I want to buy a dress to fit my daughter.' So she bought this dress and it fit her perfectly. [....] That was one story about Auntie Angela. And the other thing that she did was you know in 1979 when she came back, her daughter asked her, 'Mom how come you're dressed so crazy?' She had 4 pairs of pants on. She had t-shirts, shirts. I don't know what else she had under her clothes. I just said to her, 'How come you're dressed like this?' 'Well they told me I can't bring things across that border so I smuggled it across.' That was us First Nations in your country [the Philippines]. 
We began an interview with the first president of the Canadian Filipino Association of Yukon by explaining that our theatre piece brought the Filipino and Tlingit communities together to play bingo.

"Tlingit?!" she said. "Why are you....?" We started to explain and she interrupted "But did you know that I'm a Tlingit?" A single mother of three children living in Baguio, she met a visiting white Yukoner, and eventually married and came to live with him in Yukon. "When I arrived here," she told us, "my second boy opened a restaurant [...]. So the name of the restaurant is William's Place because my father's name is Williams. And I was carrying that as my maiden name. So this lady comes to the restaurant. And then she said, "Who is Williams?" Because that's her surname [too]. I said "Me. My son is Williams." "Why are you Williams?" "Because," I said "my father is a Williams". She said, "Oh my god, where are you from originally?" I said from the Philippines. "Oh my god", she said. "You are the one we're looking for" [thereby introducing her to a history she did not know]. Isn't that a coincidence that I married a guy from here, that's living here. So what they do is they take me to the Indian Affairs and they look at the book, the big book, and it's written. Girl. Philippines. So, I became status Indian. And all my children are status because I'm not married to the father of the kids. So my status, I'm 50\% Indian. My children carry it." Her Tlingit father met her mother in Leyte in the Philippines while serving in the Canadian navy. One the one hand this history points up the gendered dynamics of sex and race within settler colonialism: under the Indian Act non-indigenous women could acquire Indian status through marriage to an indigenous man and transmit status to their children, while indigenous women marrying non-indigenous men lost their status, with profound effects on gender 
dynamics within their own community (Hunt and Holmes, 2015; Simpson, 2014). At the same time as this woman's story retells this familiar narrative of patriarchal settler colonial legal ordering, there is something almost fantastical about it, told in a remote settlement more than an hour outside Whitehorse, in which the world is suddenly not quite as we expect. In a Benjaminian sense, it momentarily breaks the spell of ossified tradition "by cutting out what is 'rich and strange'... from what had been handed down [as History] in one solid piece" (Arendt, 1969: 42) This is a Filipino woman being found within a history of which she knew nothing, one that embeds her within the contemporary Tlingit community and confers rights to resources (e.g., a share of fish) and care (e.g., shovelling her snow) that have nothing to do with Canadian citizenship.

These stories are disruptive of colonial framings in a number of different ways. They surely disrupt static narratives of indigeneity. Tlingit people in these stories are travelling the world as tourists or while enlisted in the Canadian navy (Thrush 2016). It reclaims, in Audra Simpson's (2014) words, "fluidity of traditions and histories" that persist within and beyond classifications and "rigidities of colonialism." They are in the world, in history, in time (Deloria, 2004). The stories gesture to rich histories, unknown to Filipinos and some Tlingit in Whitehorse, of already existing relationships between Filipinos and Tlingit in the region, going back to 1791 (Mercene 2007), and in recent memory with the arrival of Filipino men in the 1920 s and 30s, who had migrated north - typically as contract labourers - to work in the seasonal Alaskan canning industry or as commercial fishermen. Many stayed, some (like Ricky's great grandfather) married into First Nations communities. Filipinos now represent the largest non-aboriginal ethnic group in Alaska (4.4\% of the population according to the 2010 US census). 
Filipino and Tlingit histories do not blur into each other but there is a complex set of intimacies that tends to be forgotten or written out of accounts; indeed Renisa Mawani (2009) traces the efforts on the part of the Canadian state to restrict such intimate connections. Silences about histories of international intimacies, like the history of Filipino and Tlingit, stop us from knowing other ways of relating, and different pasts that are also resources for imagining different futures. Reclaiming histories can open up a new political imagination based on a "contextualized and historicized understanding of the relationships between the different peoples who have interacted and co-existed in places over time" (Arat Koc, 2014: n.p.). Knowing these histories releases into the space of colonial History, "other normative and theoretical thought enshrined in other existing life practices and their archives" "For it is only in this way," Chakrabarty (2000) writes, "that we can create plural normative horizons specific to our existence and relevant to the examination of their lives and their possibilities" (20). It also creates a space for nurturing contemporary solidarities and intimacies among those who are torn apart by citizenship, and by multicultural inclusion and its violences within a settler state. 

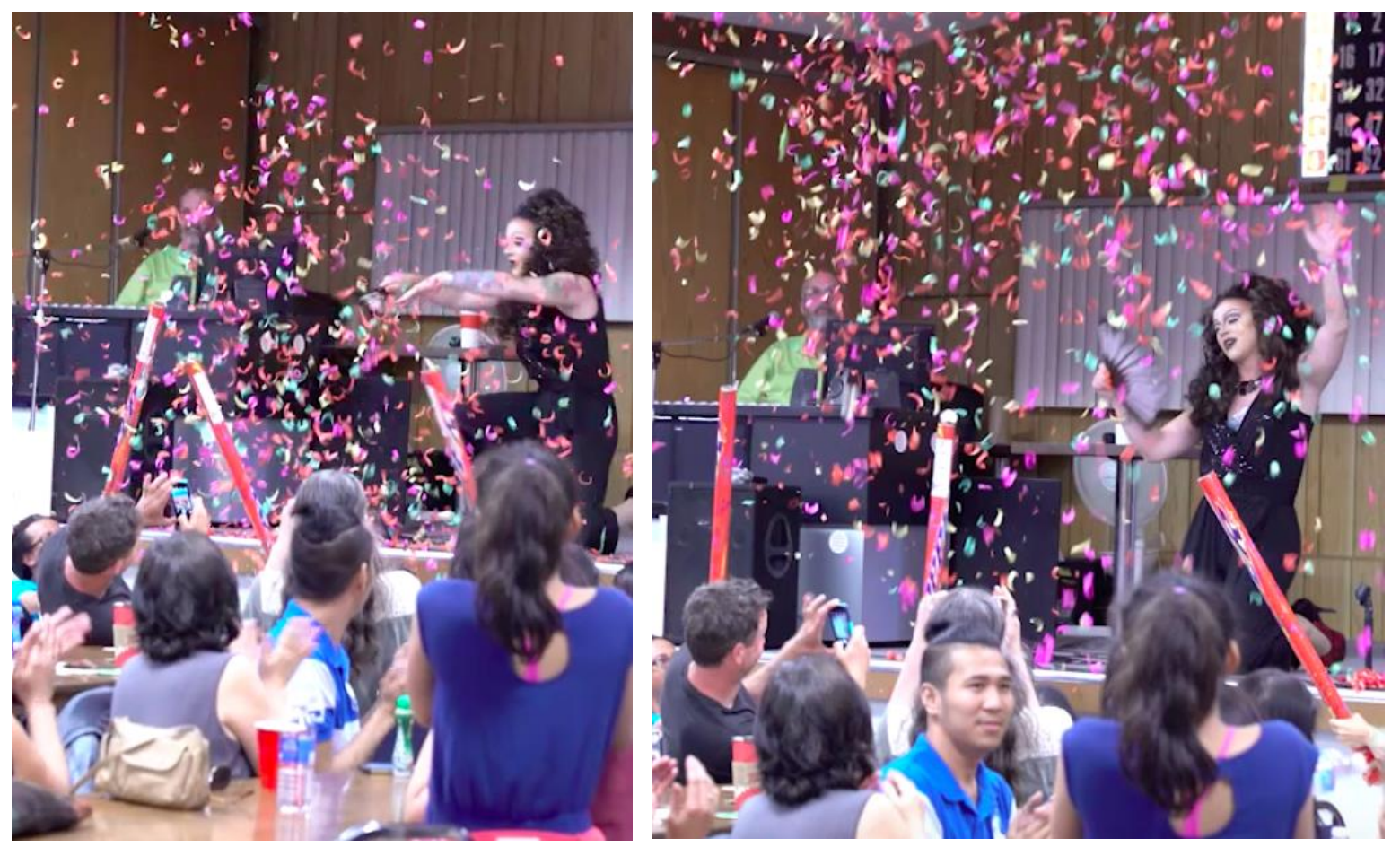

Figure 5. The grand finale. Photos by Caleb Johnston

And finally, Miss Lituya's beckoning and recognition of Ardie through the familial term, 'cousin,' is a solicitation, not from within the bourgeois private family, but through a different ontology of social relatedness (see also TallBear, 2016), one that Filipino audience members may have been able to hear in these terms. While installing the heteronormative family and norms of private domestic life were central to the U.S. government's colonial practice in the Philippines, Neferti Tadiar has argued that less individualistic and bounded ontologies of self and social belonging continue to "cut across and confound" these outcomes (2015: 147). She finds, for example, in Filipino migrant domestic workers a means of imagining forms of sociality that are illegible in typical renderings of them as racialised and exploited workers. As "conduits of other people's wills and aspirations, accommodating and conforming to the bodily, emotional, psychical, and metaphysical requirements of individuals and communities, to which they are attached as vital, component yet alienable parts, they act in a very practical but also 
otherworldly sense as forms of human media - technologies of reproduction rather than fullfledged sovereign (self-determining, self-owning) individual subjects" (2015: 152). We might also locate the practices of familial debt bondage in Whitehorse within this economy of selflending. While there is nothing inherently progressive about this, it opens other ontologies of self, other social practices, other social values and other social logics that hold possibility for unanticipated histories and plural normative horizons. They might "set the stage" Tadiar speculates, "for radical departure from the given conditions of life under empire now" (156). Tlingipino Bingo possibly set the stage for other narratives about Filipinos in Yukon, beyond those of successful nannies and hardworking Filipinos, and other models of inclusion beyond liberal citizenship. This likely would entail recognising in Gramma Susie's welcome claims to territory and agency that emerge from within traditions of hospitality somewhat different than state multicultural inclusion. Gramma Susie's welcome might be viewed as a call to relationship that sets in train expectations not only of reciprocity but responsibility and responsiveness to the agency and concerns of First Nations peoples (Kuokkanen, 2007).

Although not named in the production, Tlingipino Bingo may have generated some new possibilities for relationship with settlers as well. Consider, for example, the exchange that we had a couple of days after the event with an older white conservative Elks' Lodge volunteer, who has run bingo for the past forty years and espouses some troubling policy views -- such as drug testing of indigenous peoples in order for them to access social assistance benefits. Unprompted, he said: "I loved your performer." He persisted with genuine curiosity: "What do you call him?" [A drag queen.] "Is his lifestyle that or is he just performing?" [Yes, he's gay.] “But he doesn't dress like that everyday?" He concluded: "Yeah he's kinda neat. One of our 
bartenders was out and having a cigarette and he was out there. He told her that you guys were probably going bar hopping or something [after the show]. He said he had to get back to the hotel because he had this cute little black dress to wear." "He's kinda neat."12

\section{Unsettled}

During the intermission a white audience member came up to one of us and said with great warmth and enthusiasm that Tlingipino Bingo was the most multicultural space she had ever been in during all of her years living in Whitehorse. Sharon Shorty's story- delivered in the third round of bingo, after she stepped out of her Gramma Susie outfit and character, and returned to enjoy the game as herself - could be interpreted within this framework of multiculturalism as well. One of the prizes for what was called the Tlingipino round of bingo games was a bouquet of BBQ pork skewers prepared by the Canadian Filipino Association of Yukon (CFAY). CFAY BBQ skewers are well known in Whitehorse because CFAY prepares hundreds of them to be sold at the Whitehorse Canada Day celebrations each year. Their booth is, we were told, one of the most popular, and line-ups to purchase the skewers are long. After the prize of skewers was won, Sharon shared this story:

Here's a story about these wonderful pork skewers. Does anybody else like pork skewers on July 1st? [Cheers.] From the Yukon Filipino Association. Thank you. So, when I was dating my husband, Derek --Derek Yap stand up -- when we were dating, I told him, 'Please don't waste money on flowers. I can't eat flowers. Bring me meat on a stick. I'm an Indian woman.' So, on July 1st, on our anniversary, he comes running with 6 
skewers from the Filipino Association, saying 'Happy Anniversary!' And I was like, 'I love you.' It's true love. And now he always brings me meat on a stick.

While this could be interpreted as instantiating a quintessential state multicultural moment (sharing 'ethnic' food at a Canada Day celebration), exchanges across food (and the event of Tlingipino Bingo) might be more complex. They might unsettle rather than solidify the settlercolonial nation. A number of Filipinos with whom we spoke began to trace the foundations for a relationship with indigenous peoples in shared food traditions: "We love to eat. Wild meat"; "[There are] quite a few similarities. In terms of the food, they like fish heads, we love fish heads." Particularly with the latter observation, commonality is implicitly constructed against the recognition that many white Canadians would find fish heads repugnant.

White settlers, with the exception of artists, were allowed to participate and witness but were not fully welcomed into the Tlingipino Bingo game, and resentment built when the same white person won the first two games. The director of Tlingipino Bingo observed: "And they [the white audience member] kept on winning. What does that mean? Twice. [...] What is this? This is a game of chance, yes. But it's not. Twice over. And he was jumping [with delight]. He was jumping [when his number was called]!" It is fair to say that we, as participants in the creation and production of Tlingipino Bingo, and acting under the dubious sign of university researchers (from the south of Canada), never escaped suspicion ourselves, never found a place in the process in which to settle comfortably. Nor should we. How then can we, as white settlers, be accountable and responsive to the gift of Tlingipino Bingo, a performance emerging from Nanay ${ }^{13}$ 
In orienting towards decolonization -- a term, as white settler, Emilie Cameron uses with caution and without claiming for herself -- she urges non-indigenous scholars to not only learn the shape of our influence and claims but also the limits of those claims, and all the ways that we do not matter and do not know (2015: 14). "We must learn," she writes, "to know less, claim less, to listen, and to stop" (20). For us in the process of helping to create Tlingipino Bingo, and for all of the non-indigenous and non-Filipinos in the Elks' Lodge, the event was a lesson in listening and sometimes taking the brunt of the mockery and resentment. It was a lesson in engaging with the possibility that our presence was unwanted or at best irrelevant to that event. We need, in Cameron's wording, "to continually articulate methodological and theoretical spaces within which both the reach and limits of [settler] practices might be apprehended" (23). It is possible that Tlingipino Bingo was such a space.

Writing about Tlingipino Bingo opens another opportunity to think about and question the ongoing violence of settler colonialism in Yukon. It provides a critical space to contemplate the possibility that Filipino immigrants - without malice or intent - occupy a role within settler colonialism as a model minority discourse travels beyond the Filipino community. We write about Tlingipino Bingo so that we might better understand its political possibilities, as one means of 'setting the stage' to imagine relationship beyond citizenship. Alongside narratives of successful nannies and hard working model minorities, it seems to offer other narratives to the Filipino community (and others) in Whitehorse. These are narratives that add a layer of complexity to the stories of labour exploitation that we circulated through Nanay, the latter seeming not to gain political traction within the Filipino community there. Tlingipino Bingo may open other narratives and critical political possibilities for claiming a space in Canada in 
solidarity with indigenous peoples, possibly less imbricated within settler colonialism. Finally, we put stories of Tlingipino Bingo into circulation to express our gratitude for this gift and as a way - possibly -- of extending relations of accountability through its circulation (Kuokkanen, 2007). We accept that writing about Tlingipino Bingo may simultaneously instantiate settler colonialism in familiar ways, as we - white settlers - translate and transport the performance into the academic archive and a particular form of knowledge production. This undecidability about writing about Tlingipino Bingo keeps us attuned to the perniciousness of settler colonialism, and - we hope - nurtures the possibility for further conversation within the indigenous-arrivant- settler triad.

\section{Acknowledgements}

We very much appreciate the invitation from the Society and Space editors to present this paper at the annual meetings of the AAG (and to Natalie Oswin for making the arrangements), as well as feedback from participants at the Reimaging Creative Economy Workshop in Edmonton Alberta, May 2017. We thank Alistair Bonnett, Emilie Cameron, John Paul Catungal, Dia Da Costa, Julie Cruikshank, Michelle Daigle, Jess Dempsey, Dennis Gupa, Diyah Larasati and Juanita Sundberg for their close reading of and helpful comments on a draft of this paper. We take responsibility for all errors and/or misunderstandings. This research was made possible through funding by the UBC Faculty of Arts, and CFI (Grant \#33361). For making Tlingipino Bingo possible, we thank the Yukon Arts Fund, Whitehorse Nuit Blanche, and Culture Quest. We thank all member of the 'Conversation Collective' for their willingness to collaborate on this project, Marivic Perlawan for her participation in Tlingipino Bingo and permission to use her 
image here, and CFAY for their generosity and enthusiasm, for their hard work getting the Filipino community out, for catering for the event, and for their delicious BBQ skewers. We thank Vanessa Banta and Anna Crawford for permission to use their photographs.

\section{Notes}

${ }^{1}$ In this we are part of what Sarah de Leeuw and Harriet Hawkins (2017) have termed geography's 'creative turn'. See also Marston and de Leeuw (2013) and Rogers (2017).

${ }^{2}$ Filipina mothers coming through Canada's Live-in Caregiver Program (the focus of Nanay) experience long periods of separation from their children before they gain permanent resident status and the right to sponsor their children's migration to Canada (Pratt, 2012).

${ }^{3}$ It also emerged out of a different time frame of collaboration: an ongoing fifteen-year collaboration between a white scholar (Pratt) and the Philippine Women Center over the course of five different research projects.

${ }^{4}$ Our intention was to support the project through initial funding and grant writing and to document the production that came out of this. As the project evolved, for a variety of workrelated, health and personal reasons we took on a more central role creating the structure of the show in collaboration with others, and as producers of the performance.

${ }^{5}$ The research was conducted over the course of four trips to Whitehorse, which ranged from 3 days to two weeks. Along with participating in performance development, formal interviews were carried out with thirteen members of the Filipino community in Whitehorse, as well as two government representatives and a representative of the Elks Lodge. 
${ }^{6}$ In recent years the program has become more closely regulated: the government has added a language requirement, contacts the prospective employer and more closely scrutinizes the suitability of work experience: “It's not like ‘I work as a scuba diving instructor and now I'm going to work as a food and counter attendant at McDonalds.' You need to demonstrate that you worked for the food industry for a minimum of 6 months. [...] Before we kind of took your word for it, now we actually contact employers."

${ }^{7}$ We thank Emilie Cameron for this wording.

${ }^{8}$ In the US context, David Pulumbo-Liu (1999) documents the ways that white supremist ideology has been channelled through the body of the Asian American, in particular, its capacity for hard work, perseverance and independence from state or federal largesse. Byrd argues that the Asian body now bears and takes forward the 'cowboys and indians' narrative in the United States. To sustain this point she draws on Pulumbo-Liu's analysis of popular media representations of Korean Americans during the Los Angeles riots in 1992 as vigilante 'cowboys' protecting their property from looting by African Americans.

${ }^{9}$ We thank Emilie Cameron for this phrasing.

${ }^{10}$ Reflecting on his celebrated theatre play, The Rez Sisters, which revolves around the journeys of seven bingo-obsessed indigenous women in Southern Ontario after they hear rumour that the world's biggest bingo game is coming to Toronto, Tomson Highway has observed, "I'm sure some people went to Rez expecting crying and moaning and plenty of misery, reflecting everything they've heard about or witnessed on reserves. They must have been surprised. All that humour and love and optimism, plus the positive values taught by Indian mythology." Thomas King, the celebrated American-Canadian Indigenous writer and humourist, speaking 
about his work on the Canadian radio series Dead Dog Café, explains how he turned to humour as a "survival strategy... If life is so bad, you either kill yourself or you laugh. Colonized people can see humour as a strength, as a medicine" (Stackhouse, 2001). "I’m dealing with cultural humour," he says, "And occasionally, I'm going to hold that mirror up to white Canada, and say, 'See this is what it feels like'. [...] You can get into the back door with humour. You can get into their kitchen with humour. If you're pounding on the front door, they won't let you in" (Taylor, 2000).

${ }^{11}$ Filipino immigration to Canada is understudied more generally. As a corrective to this tendency, see Coloma et al. 2012.

${ }^{12}$ See Hunt and Holmes (2015) for the significance of daily actions in everyday spaces for decolonial processes and practices.

${ }^{13}$ Another approach would be to respond seriously to the questioning we received about our own ancestry and to situate ourselves more precisely within the historical narratives we seek to disturb. Analysing the US media's focus on and representation of Korean American and African American conflict during Los Angeles Riots of 1992, Pulumbo-Liu notes that it left white Americans "free both to stand apart and speculate" on the conflict (1999: 193). Witnessing settler colonialism and conflict between Filipinos and First Nations without implication seems to repeat this dynamic. Just a little research into our family histories reveals historical complicities that are more immediate and more intimate than we had imagined, and our ignorance of these histories is itself politically significant. Caleb learned more concerning the move of his grandparents to Whitehorse with their four children in 1964, driving north from Vancouver on a gravel road to settle in purpose-built government housing designed for the civil service and 
army. His grandfather had taken a job with the Ministry of Indian Affairs, working as a councillor in the territory's residential schools. He was - by lineage - implicated in aggressive state policy designed to enact the violent assimilation and/or cultural annihilation of indigenous peoples in the Yukon, implicated in a horrendous 'civilising' strategy that forcibly removed indigenous children from their family homes, stripping them of their ancestral languages, exposing many to horrific abuse. We rented accommodation in the same housing development during our stay in Whitehorse. Gerry's great great grandmother, Valdis Gudmundsdottir, was among the first 365 Icelandic settlers to arrive in New Iceland, on the shores of Lake Winnipeg in Manitoba in 1875, three days after the Dominion Order-in-Council granted the Icelanders their 600-square mile block settlement reserve. This land was by no means vacant or uncontested, and was in fact granted before aboriginal title was extinguished (Brydon, 2001). Granting inclusion to European migrants while simultaneously suspending the rights of another as part of a larger state effort to eliminate the latter is, as Laurie Bertram (2011) observes, "the early expression of sovereign-power through the creation of race-based states of exception, or the erosion or suspension of the rights of a certain population as part of a larger attempt to eliminate that population" (162). The Icelanders were part of a state-coordinated population transformation known as the "peopling of the prairies" (ibid: 162). As a talented midwife, Valdis contributed to this biopolitical project by midwifing the birth of the first Icelander born in Canada. On the other side of biopolitics, Icelanders brought smallpox that killed 10 percent of the Icelanders and 70 percent of the local indigenous population (ibid). Valdis and her husband Simon Simonarson lived intimately with these deaths, taking into their home a number of children whose Icelandic parents had died of small pox. Anglo-Canadians termed Icelanders 
'squawmuck' and characterised them as a 'seal skin wearing and blubber eating race.'

Icelanders worked to whiten themselves in their early years in Manitoba, and in an effort to reform the community's image, the Icelandic elite in the 1880s initiated a campaign to support the government's war against indigenous land claims and to suppress the Northwest Rebellion (Bertram, 2014). My great great step-grandfather fought in this war. Our point in pursuing this strategy would not be to re-center whiteness or to seek a space of reconciliation within Tlingipino Bingo; it is to say, yes, we carry family histories that put us into this picture as well, and intimately so, and to say that colonialism is an active and on-going process, including the process of becoming white. Writing these histories into our account of Tlingipino Bingo could be seen as one effort to disrupt "the habit among settlers of imagining that we are somehow not involved" (Cameron, 2015: 17). Now more than ever, claiming such histories could be a means to simultaneously assert and unsettle our claims to nation space in an effort to disrupt the nostalgia for a lost time of national whiteness. To un(document) oneself or to trace the arbitrary and tenuous legal nature of one's inclusion is possibly an act of solidarity with those who live their lives without full benefits of citizenship. Still, in the context of Tlingipino Bingo, the specificity of our history does not alter our participation. As such we may be more appropriately left to embody with discomfort our assigned roles as representatives of a structure of privilege. We thank Emilie Cameron for this point. We thank Sarah Hunt and Cindy Holmes (2015) for their clear articulation of the distinction between a politics of accountability and a politics of inclusion in relations of allyship. 


\section{References}

Alarcon K (2013) First Filipina nanny helped community grow. Yukon News, August 30, p. 34.

Arendt H (1969) Introduction: Walter Benjamin: 1892-1940. In: Translated by Zohn H, Benjamin W Illuminations, New York: Schocken Books, pp. 1-55.

Arat-Koç S (2014) An anti-Colonial politics of place. In: Stanley A, Arat-Koc S, Bertram L and King $\mathrm{H}$ Intervention - Addressing the Indigenous-Immigration 'Parallax Gap'. Antipode, available at: https://antipodefoundation.org/2014/06/18/addressing-the-indigenous-immigration-parallaxgap/

Bertram L (2011) Resurfacing landscapes of trauma: Multiculturalism, cemeteries, and the migrant body, 1875 onwards. In: Chazon M, Helps L, Stanley A andThakkar S (eds) Home and Native Land: Unsettling Multiculturalism in Canada. Toronto: Between The Lines, pp. 157-174.

Bertram L (2014) Icelandic and indigenous exchange, overlapping histories of migration and colonialism. In: Stanley A, Arat-Koc S, Bertram L and King H Intervention - Addressing the Indigenous-Immigration 'Parallax Gap'. Antipode, available at:

https://antipodefoundation.org/2014/06/18/addressing-the-indigenous-immigration-parallaxgap/ 
Brydon A (2001) Dreams and claims: Icelandic-Aboriginal interactions in the Manitoba interlake. Journal of Canadian Studies 36: 164-190.

Byrd J (2011) Transit of Empire: Indigenous Critiques of Colonialism Minneapolis, London: University of Minnesota Press.

Cameron E (2015) Far Off Metal River: Inuit Lands, Settler Stories, and the Making of the Contemporary Artic, Vancouver: University of British Columbia Press.

Cannell F (1999) Power and Intimacy in the Christian Philippines, Cambridge: Cambridge University Press.

Chakarbarty D (2000) Provincializing Europe: Postcolonial Thought and Historical Difference, Princeton, N.J.: Princeton University Press.

Chazon M, Helps L, Stanley A and Sonali T (eds) (2011) Home and Native Land: Unsettling Multiculturalism in Canada, Toronto: Between The Lines.

Clarkson J (2015) Foreign workers take jobs that nobody else wants. Yukon News, March 11.

Coloma R S, McElhinny B T, Ethel C, John P C and L M Davidson (eds) (2012) Filipinos in Canada: Disturbing Invisibility, Toronto: University of Toronto Press. 
Davidson L (2012) (Res)sentiment and practices of hope: The labours of Filipina Live-In Caregivers in Filipino Canadian Families. In: Coloma RS, McElhinny B, Tungohan E, Catungal JPC and Davidson LM (eds) Filipinos in Canada: Disturbing Invisibility, Toronto: University of Toronto Press.

Day I (2016) Alien Capital: Asian Racialization and the Logic of Settler Colonial Capitalism, Duke University Press.

De Leeuw S and Hawkins H (2017) Critical geographies and geography's creative turn: poetics and practices for new disciplinary spaces. Gender, Place and Culture: A Journal of Feminist Geography 24(3): 303-324.

De Souza R (2012) The Yukon is the north, pure and simple. National Post, June 7 A10. Deloria P J (2004) Indians in Unexpected Places, Lawrence: University of Kansas Press.

Everett-Green R (2017) Kent Monkman: a trickster with a cause crashes Canada's $150^{\text {th }}$ birthday party. Globe and Mail, 7 January.

Fagan K (2001) Laughing to Survive: Humour in Contemporary Canadian Native Literature, Unpublished PhD Thesis: University of Toronto. 
Farrales M (2017) Basketball, Beauty Pageants and the Sexualities of Filipinos in Canada, Unpublished PhD dissertation, Geography: University of British Columbia.

Hedman ELE and Sidel JT (2000) Philippine Politics and Society in the Twentieth Century: Colonial Legacies, Post-Colonial Trajectories, London: Routledge.

Highway T (1990) The Rez Sisters: A Play in Two Acts. Fifth House.

Hill R (2001) Drag Racing: dressing up (and messing up) white in contemporary First Nations art. Fuse Magazine 23(4): 18-27.

Honig B (1998) Immigrant America? How foreignness 'solves' democracy's problems. Social Text 56: 1-27.

Hopper T (2009) Foreign workers championed despite slowdown Yukon News, April 3, p. 7.

Hunt S and Holmes C (2015) Everyday decolonization: Living a decolonizing queer politics. Journal of Lesbian Studies 19: 154-172.

Johnston C and Pratt G (2014) Taking Nanay to the Philippines: Transnational circuits of affect. In: Hurley E (ed) Theatres of Affect, Toronto: University of Toronto Press, pp. 192-212. 
Keevil G (2016) The Philippine connection: How one woman turned Whitehorse into a promised land. The Walrus, June.

Kuokkanen R (2007) Reshaping the University: Responsibility, Indigenous Epistemes, and the Logic of the Gift, Vancouver: University of British Columbia Press.

Lawrence B and Enakshi D (2005) Decolonizing antiracism. Social Justice 32(4): 120-143.

Lowe L (2015) The Intimacies of Four Continents, Durham and London: Duke University Press.

Manalanson M (2003) Global Divas: Filipino Gay Men in Diaspora, Durham, NC and London:

Duke University Press.

Marston S and de Leeuw S (2013) Creativity and geography: Towards a politicized intervention. Geographical Review 103 (2): iii-xxvi.

McKegney S (2005) From trickster poetics to transgressive politics: Substantiating survivance in Tomson Highway's Kiss of the Fur Queen. Studies in American Indian Literatures 17(4): 79-113.

Mercene F (2007) Manila Men in the New World: Filipino Migration to Mexico and the Americas from the Sixteenth Century, Quezon: University of the Philippines Press. 
Mikdashi M (2013) What is settler colonialism? (for Leo Delano Ames, Jr.). American Indian Culture and Research Journal 37(2): 23-34.

Miller S C (1982) Benevolent Assimilation: The American Conquest of the Philippines, 18991903, New Haven: Yale University Press.

Mawani R (2009) Colonial Proximities: Crossracial Encounters and Juridical Truths in British Columbia 1871-1921, Vancouver: University of British Columbia Press.

Morgensen S L (2011) Unsettling queer politics: What can non-natives learn from two-spirit organizing? In: Qwo-Li D, Finley C, Killey BJ and Lauria Morgensen SL (eds) Queer Indigenous Studies: Critical Interventions in Theory, Politics, and Literature, Tucson: University of Arizona Press, pp 132-154.

Oke C (2011) Yukon retains its foreign workers. Yukon News, June 8, p. 3.

Pratt G (2012) Families Apart: Migrant Mothers and the Conflicts of Labor and Love, Minneapolis and London: University of Minnesota Press.

Pratt G and Johnston C in collaboration with the Philippine Women Centre of BC (2014) Nanay (Mother): A Testimonial Theatre Play. In E Hurley (ed) Once More, With Feeling: Six Affecting Plays, Toronto: University of Toronto Press, pp. 49-90. 
Pratt G, Johnston C and Banta V (2017) A travelling script: Labour migration, precarity and performance. The Drama Review 61(2): 48-70.

Pulumbo-Liu D (1999) Asian/American: Historical Crossings of a Racial Frontier, Stanford: Stanford University Press.

Rogers A (2017) Advancing the geographies of the performing arts: Intercultural aesthetics, migratory mobilities and geopolitics. Progress in Human Geography.

Ronson J (2013) Film fest brings world stories home. Yukon News, February 1.

Ryan A (1999) The Trickster Shift: Humour and Irony in Contemporary Native Art, Vancouver: UBC.

Saranillio D (2013) Why Asian settler colonialism matters: a thought piece on critiques, debates, and Indigenous difference. Settler Colonial Studies 3: 280-294.

Simpson A (2014) Mohawk Interruptus: Political Life Across the Borders of Settler States, Durham and London: Duke University Press.

Stackhouse J (2001) Comic heroes or 'red niggers'? Globe and Mail, Friday 9 November. 
Stanley A, Arat-Koc S, Bertram L and King H (2014) Intervention - addressing the indigenousimmigration 'parallax gap'. Antipode, available at:

https://antipodefoundation.org/2014/06/18/addressing-the-indigenous-immigration-parallax-

gap/

Swanson K (2012) The noble savage was a drag queen: Hybridity and transformation in Kent Monkman's performance and visual art interventions. In: Fitzgerald M and Rayter S (eds) Queerly Canadian An Introductory Reader in Sexuality Studies, Toronto: Canadian Scholars Press, pp. 565-576.

Tadiar NXM. (2015) Decolonization, 'race', and remaindered life under empire. Qui Parle 23(2): 135-160.

TallBear K (2016) Making Love and Relations Beyond Settler Sexualities. https://www.youtube.com/watch?v=rICFnEDRIts. Accessed June 82017. Taylor DH (2000) Redskins, Tricksters and Puppy Stew. National Film Board of Canada. Thompson J (2010) Territory to expand foreign worker program. Yukon News June 18, p. 5. 
Thrush C (2016) Indigenous London: Native Travelers at the Heart of Empire, New Haven: Yale University Press.

Tuck E and Wang K (2012) Decolonization is not a metaphor. Decolonization: Indigeneity, Education \& Society 1(1): 1-40.

Vizenor G (1994) Manifest Manners: Postindian Warriors of Survivance, Hanover: Wesleyan UP.

Walcher W (2014) Cold Paradise. Cold Paradise Productions DVD.

Wingrove J (2014) Filipino community thrives in Yukon; streamlined path to entry, residency appeals to immigrants who come to work. The Globe and Mail, January 23, A4.

Wolfe P (2006) Settler colonialism and the elimination of the native. Journal of Genocide Research 8(4): 387-409.

Wong R (2008) Decolonization: Reading Asian and First Nations relations in literature. Canadian Literature 199: 158-180. 